Article

\title{
Aquifer Thermal Energy Storage (ATES) for District Heating and Cooling: A Novel Modeling Approach Applied in a Case Study of a Finnish Urban District
}

\author{
Oleg Todorov ${ }^{1, *(\mathbb{D})}$, Kari Alanne ${ }^{1}$, Markku Virtanen ${ }^{1}$ and Risto Kosonen ${ }^{1,2}(\mathbb{D}$ \\ 1 Department of Mechanical Engineering, Aalto University, 02150 Espoo, Finland; kari.alanne@aalto.fi (K.A.); \\ markku.j.virtanen@aalto.fi (M.V.); risto.kosonen@aalto.fi (R.K.) \\ 2 College of Urban Construction, Nanjing Tech University, Nanjing 211800, China \\ * Correspondence: oleg.todorovradoslavov@aalto.fi
}

Received: 17 March 2020; Accepted: 11 May 2020; Published: 14 May 2020

check for updates

\begin{abstract}
Aquifer thermal energy storage (ATES) combined with ground-source heat pumps (GSHP) offer an attractive technology to match supply and demand by efficiently recycling heating and cooling loads. This study analyses the integration of the ATES-GSHP system in both district heating and cooling networks of an urban district in southwestern Finland, in terms of technoeconomic feasibility, efficiency, and impact on the aquifer area. A novel mathematical modeling for GSHP operation and energy system management is proposed and demonstrated, using hourly data for heating and cooling demand. Hydrogeological and geographic data from different Finnish data sources is retrieved in order to calibrate and validate a groundwater model. Two different scenarios for ATES operation are investigated, limited by the maximum pumping flow rate of the groundwater area. The additional precooling exchanger in the second scenario resulted in an important advantage, since it increased the heating and cooling demand covered by ATES by $13 \%$ and $15 \%$, respectively, and decreased the energy production cost by $5.2 \%$. It is concluded that dispatching heating and cooling loads in a single operation, with annually balanced ATES management in terms of energy and pumping flows resulted in a low long-term environmental impact and is economically feasible (energy production cost below $30 € / \mathrm{MWh}$ ).
\end{abstract}

Keywords: aquifer thermal energy storage (ATES); ground-source heat pump (GSHP); district heating and cooling; ATES integration; mathematical and groundwater modeling; MODFLOW

\section{Introduction}

According to Eurostat, in 2018, the share of renewable energy sources (RES) used for heating and cooling in EU was $21 \%$ and several countries, like Sweden (65\%), Latvia (56\%), Finland (55\%) and Estonia (54\%), covered more than half of their heating and cooling consumption with renewable sources [1]. The variability of renewable generation between heating and cooling seasons, as well as the low coincidence between supply and demand are important challenges for RES penetration, therefore short- and long-term energy storage is needed for maximizing the usage of RES. Aquifer thermal energy storage (ATES) is an attractive technological option suitable for large buildings and utilities as well as capable to enable important storage capacities [2,3]. Moreover, the utilization of GSHP operating within the urban subsurface space, is an efficient and resilient alternative for sustainable generation of heating and cooling energy in a district level [4].

The potential of ATES integration as a part of sustainable heating and cooling in combination with a ground-source heat pump (GSHP) for energy recovery from the subsurface has been acknowledged worldwide. Fleuchaus et al. [3] presented a complete overview of global ATES development and 
application: nowadays some 3000 ATES systems are operated worldwide. The Netherlands with $85 \%$ of all ATES realizations, followed by Sweden, Denmark and Belgium, are the undisputed frontrunners. Schmidt et al. [5] revealed that there are some 100 large-scale utility ATES systems utilized in district heating (DH) and cooling (DC) networks.

Normally, the long-term impact of ATES utilization is a combination of thermal, hydrological, microbiological and chemical impact on the affected aquifer and should be thoroughly investigated [6]. The regulation of shallow geothermal plants (depth below $400 \mathrm{~m}$ ) varies significantly among countries [7]. Countries like Denmark, the Netherlands and Austria limit the lower and higher storage temperatures, whereas France and Switzerland establish a maximum fluctuation of groundwater temperature. Finland has no explicit legislative references to groundwater utilization for thermal storage, thus the findings of the present work can contribute for developing a specific normative framework in the future.

In the same line, the ground-source heat pump (GSHP) is a key technology for decarbonization of existing heating and cooling, which are nowadays mostly based on the use of fossil fuels [8-10]. The work of Paiho et al. [8] revealed the importance of large-scale heat pumps for increasing the flexibility of Finnish energy systems. Within the same research, different examples are presented for heat pump integration in Finnish DH-DC networks_including the Kakola plant in Turku utilizing heat from sewage wastewater, and the Katri Vala plant in Helsinki generating heating and cooling in a single operation.

Fleuchaus et al. [11] evaluated the performance of ATES based on different criteria and concluded that ATES integration into heating and cooling systems was rarely addressed. In order to fill this gap, the integration of GSHP in tandem with ATES within the existing DH-DC networks of a Finnish urban district is presented and developed in the current case study. The main objective of this work is to propose a mathematical modeling of the whole ATES-GSHP-DH-DC energy chain in order to improve the system's energy management, as well as to study its technical and economic feasibility and the long-term environmental impact. Finnish public data sources are available, like the Finnish Environmental Institute (SYKE) regarding the hydrological resources, the Geological Survey of Finland (GTK) on hydrogeological conditions, and the National Land Survey of Finland (NLSF) for geographical data. The present research also introduces a methodology for fetching data from the aforementioned sources in order to calibrate and validate a groundwater model of the studied area, which in turn is an indispensable tool for studying the ATES-GSHP impact in the long-term.

\section{Materials and Methods}

The modeling procedure of the combined ATES-GSHP-DH-DC system, depicted in Figure 1, is based on the following steps, namely, (i) input data of the target DH-DC networks and the nearby groundwater areas, (ii) perform mathematical modeling of combined ATES-GSHP operation, (iii) undertake technoeconomic and sensitivity analysis, and iv) study the impact of ATES operation on aquifer areas, by developing and calibrating a specific groundwater model. A groundwater model based on the finite difference method code MODFLOW (Harbaugh et al. [12]) has been adopted and developed in the present case study. The model is calibrated against long-term data (hydraulic heads of the observation wells). The particular case study is introduced in Section 2.1, while a detailed explanation and demonstration of the modeling procedure is presented in Sections 2.2 and 2.4. 


\begin{tabular}{|c|c|}
\hline $\begin{array}{c}\text { ii) Mathematical } \\
\text { modeling of ATES-GSHP } \\
\text { operation: }\end{array}$ & $\begin{array}{l}\text { iii) Techno-economic } \\
\text { analysis of ATES } \\
\text { operation: }\end{array}$ \\
\hline $\begin{array}{l}\text { Analytical solution for HP } \\
\text { condenser recirculation } \\
\text { flow rate and HP supply } \\
\text { temperature }\end{array}$ & $\begin{array}{c}\text { Annual DH / DC demand } \\
\text { covered by GSHP-ATES } \\
\text { Annual electricity demand for } \\
\text { pumping }\end{array}$ \\
\hline $\begin{array}{l}\text { COP calculation } \\
\text { Algorithm for estimation of }\end{array}$ & $\begin{array}{l}\text { Investment cost considering } \\
\text { GSHP, exchangers, pumping } \\
\text { wells and piping }\end{array}$ \\
\hline $\begin{array}{l}\text { Calculation of pumping } \\
\text { power demand from HP to } \\
\text { DH/DC networks }\end{array}$ & $\begin{array}{c}\text { Annualized cost based on } \\
\text { investment, O\&M and } \\
\text { electricity }\end{array}$ \\
\hline 4 & heating/cooling energy \\
\hline $\begin{array}{l}\text { i) Input data for DH and } \\
\text { DC annual demand }\end{array}$ & $\begin{array}{l}\text { Sensitivity analysis of } \\
\text { system's operation }\end{array}$ \\
\hline (ho & \\
\hline $\begin{array}{l}\text { i) Input data from public } \\
\text { Finnish data sources } \\
\text { SYKE, NLSF, GTK }\end{array}$ & $\begin{array}{l}\text { iv) Impact of ATES } \\
\text { operation on aquifer area } \\
\text { (groundwater model) }\end{array}$ \\
\hline
\end{tabular}

Figure 1. General modeling procedure of the system based on aquifer thermal energy storage (ATES), ground-source heat pumps (GSHP), district heating (DH), and district cooling (DC).

\subsection{Input Data for GSHP-ATES Integration}

\subsubsection{Input Data of the DH and DC Networks}

The target district heating and cooling networks are located in the central district of Kupittaa in the town of Turku, located in the southwest part of Finland. The available data is hourly-based and the most relevant parameters of both DH and DC networks are summarized in Table 1 and Figure 2.

Table 1. Relevant DH-DC network parameters of Kupittaa district in Turku.

\begin{tabular}{ccc}
\hline Relevant Network Parameters & DH Network & DC Network \\
\hline Annual energy demand, MWh & 67,971 & 12,382 \\
\hline Maximum/minimum load, MW & $27.060 / 0.426$ & $6.378 / 0.524$ \\
\hline Average load ( \pm standard deviation), MW & $7.76 \pm 4.8$ & $1.41 \pm 0.7$ \\
\hline Maximum/minimum supply temperature, ${ }^{\circ} \mathrm{C}$ & $110.4 / 56.0$ & $10 / 5.3$ \\
\hline Average supply temperature $\left( \pm\right.$ standard deviation), ${ }^{\circ} \mathrm{C}$ & $84.3 \pm 7.8$ & $6.6 \pm 0.3$ \\
\hline Maximum/minimum return temperature, ${ }^{\circ} \mathrm{C}$ & $51.4 / 22.7$ & $14.8 / 10.0$ \\
\hline Average return temperature $\left( \pm\right.$ standard deviation), ${ }^{\circ} \mathrm{C}$ & $40.9 \pm 2.8$ & $13.5 \pm 0.4$ \\
\hline
\end{tabular}




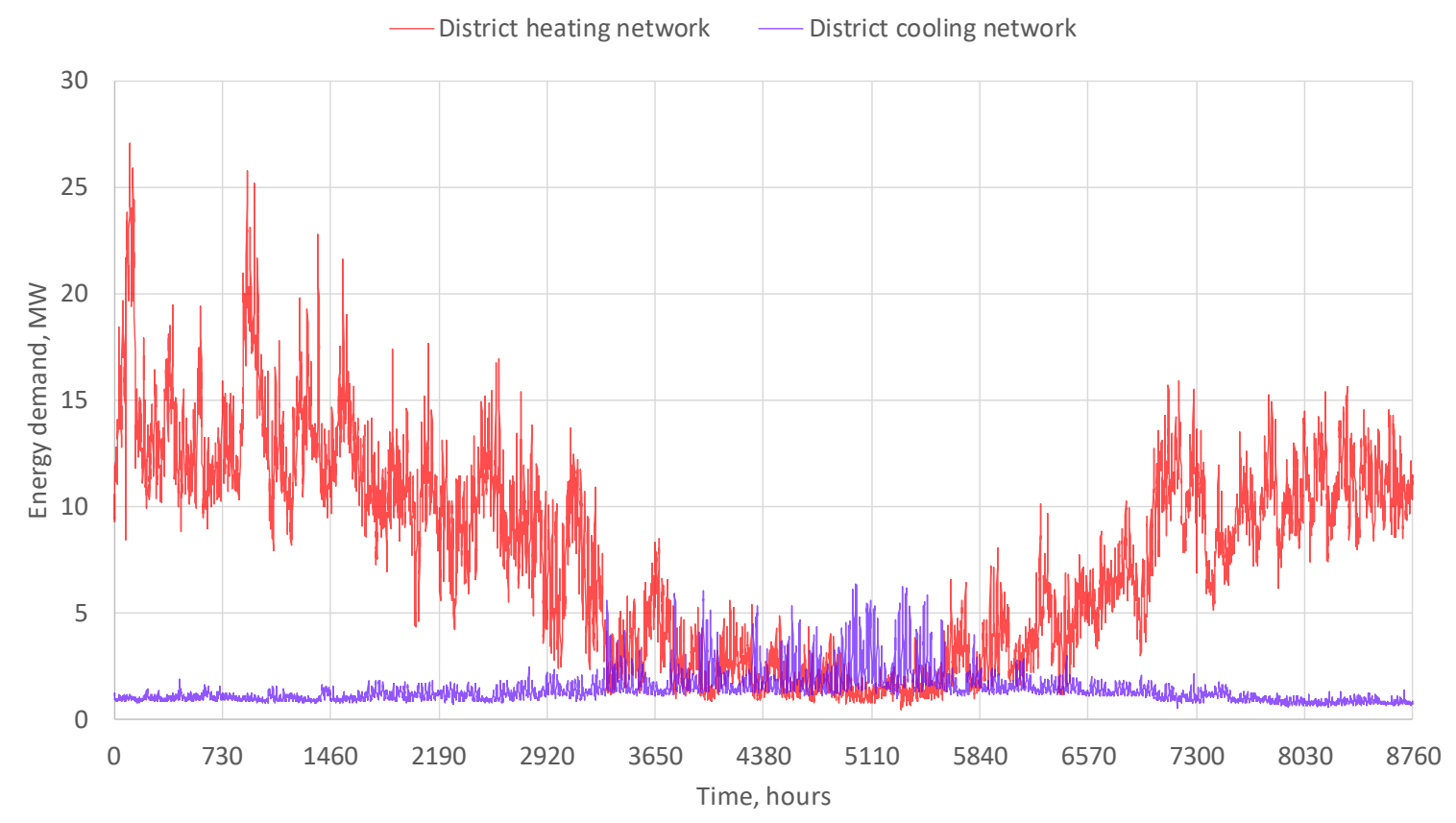

Figure 2. Annual energy demand of Kupittaa DH-DC networks.

\subsubsection{Input Data of the Groundwater Areas}

Available open data from Finnish public sources was retrieved for characterizing the target groundwater areas. In this research, data from Finnish Environment Institute [13] was used relative to groundwater areas, monitoring stations, and observation wells. Available information was utilized for 15 observation wells located in HK-Ruokatalo area of Kupittaa district and eight wells in the Kaarninko area, and their long-term statistical data for average head were used for steady-state model calibration. In the HK-Ruokatalo area, the average measured head was $16.7 \mathrm{~m}$ above sea level with standard deviation $0.7 \mathrm{~m}$, while for Kaarninko area these values were $19.3 \mathrm{~m}$ and $0.5 \mathrm{~m}$ respectively. The average aquifer thickness was estimated as $10 \mathrm{~m}$ (Joronen [14]) and the maximum allowed daily pumping rate was $2500 \mathrm{~m}^{3} /$ day. The undisturbed aquifer temperature in HK-Ruokatalo area was around $10^{\circ} \mathrm{C}$, quite high due to the subsurface heat island effect observed in cities (Bayer et al. [15]).

\subsubsection{Geographical Data}

Open data from the National Land Survey of Finland [16] was used, particularly its " 10 m elevation model". The elevation model was retrieved as Geo-TIFF raster file and transformed to Surfer Grid file (GRD) using QGIS software [17]. The Aura River, a half-kilometer to the northwest, as well as the Baltic Sea, located several kilometers to southwest establish the hydrogeological boundaries of the groundwater model.

\subsection{ATES-GSHP Integration for District Heating and Cooling}

A ground-source heat pump (GSHP), operating with an abstraction and injection well (well doublet) was considered. The condenser side of the heat pump is connected to DH network while the evaporator side is connected to aquifer pumping stream.

In the base (first) scenario, the ATES pumping flow path encounters two serial exchangers-HP evaporator and cooling for DC network. In the second scenario before the HP evaporator, a precooling exchanger is added, providing a first stage cooling to the DC network. As will be shown in the result section, with this configuration the DC demand can be more efficiently covered and GSHP efficiency (COP) can be improved since heat pump inlet temperature increases several degrees after a precooling exchanger. ATES-GSHP integration within the existing DH-DC networks is depicted in the general scheme presented in Figure 3, where temperature values illustrate the second scenario setup. 


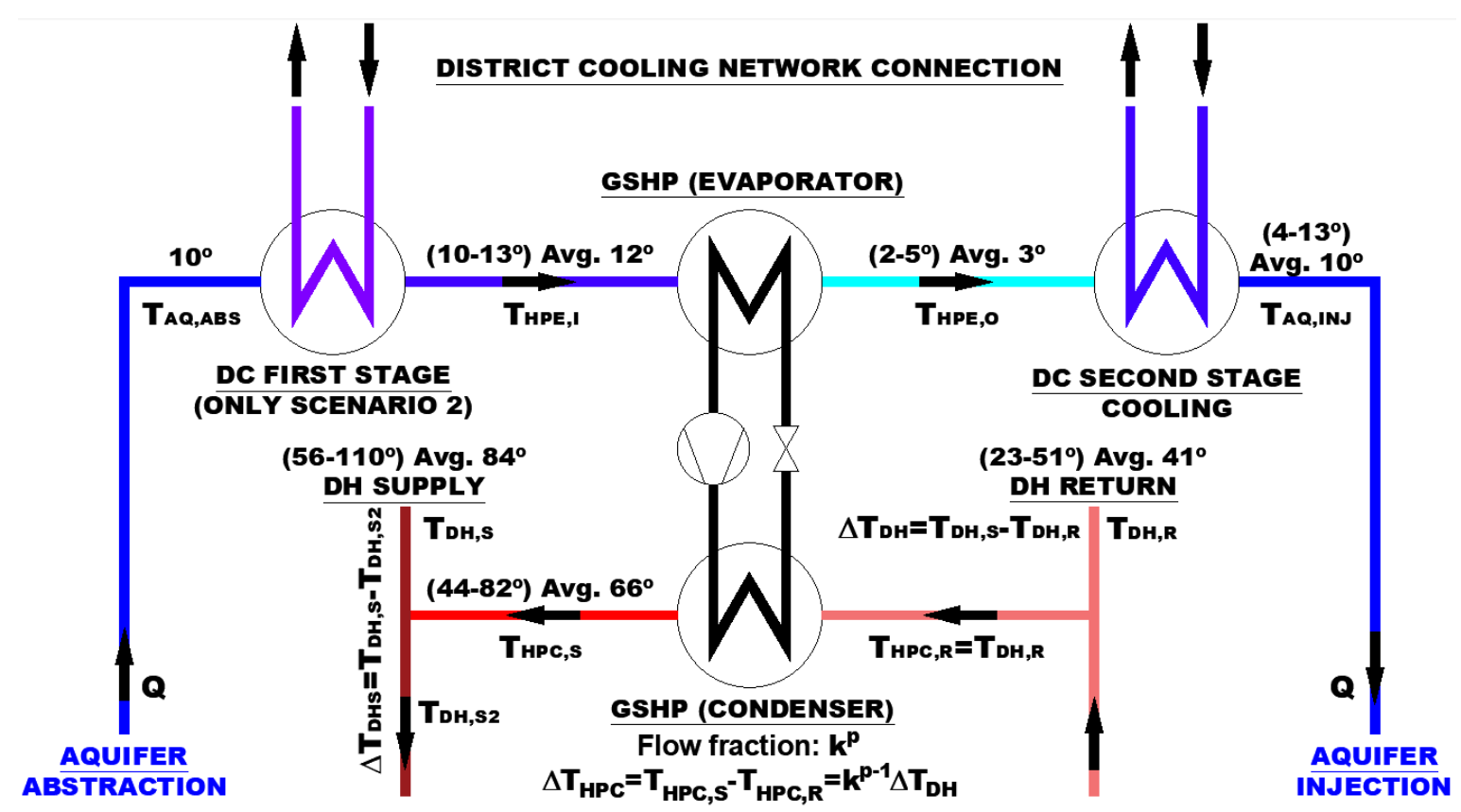

Figure 3. General scheme of ATES integration in DH-DC networks.

\subsection{Modeling Tools and Methods}

\subsubsection{GSHP Utilization for District Heating}

Generally speaking, GSHP is utilized to recover and upgrade all excess heat proceeding from the DC network and inject it in DH network. In this context ATES is utilized for balancing the energy system and mitigating the variability and no-coincidence of the simultaneously dispatched heating and cooling loads. For this purpose, heat pump supply temperature is calculated, based on the demanded power fraction $k$ (the ratio between heat supplied by the heat pump and total heat demanded in the DH branch). The flow fraction recirculated through HP condenser can be calculated as: $k^{p}$, where $0 \leq p$ $\leq 1$ is additional exponent parameter, thus the ratio between heat pump condenser $\triangle T_{H P C}$ and total $\Delta T_{D H}$ of DH network is $k^{1-p}$. Therefore, for each hour $n$, given that $T_{D H, R, n}$ and $T_{D H, S, n}$ are $D H$ return and supply temperatures respectively, the heat pump supply temperature $T_{H P C, S, n}$ can be calculated as follows:

$$
T_{H P, S, n}=T_{D H, R, n}+\left(T_{D H, S, n}-T_{D H, R, n}\right) k^{1-p} \Rightarrow \Delta T_{H P C, n}=\Delta T_{D H, n} k^{1-p}
$$

The resulting supply temperature $T_{D H, S 2, n}$ after mixing can be calculated as:

$$
T_{D H, S 2, n}=T_{D H, R, n}+\left(T_{D H, S, n}-T_{D H, R, n}\right)\left(k^{p}-k\right) \Rightarrow \Delta T_{D H, S, n}=\Delta T_{D H, n}\left(k^{p}-k\right)
$$

In the present case study, the exponential parameter $p$ was chosen to equal 0.6. It can be observed that there is a significant advantage in partial load operation, since there is no need to increase HP supply temperature as high as DH supply, thus boosting the COP. For example, for power fraction $k=0.4$ and $\Delta T_{D H}=40^{\circ} \mathrm{C}$, the GSHP should elevate $\mathrm{DH}$ return temperature by roughly $28^{\circ} \mathrm{C}$ instead of $40^{\circ} \mathrm{C}$. After mixing with the supply $\mathrm{DH}$ flow, the maximum temperature drop of the flow $\Delta T_{D H S}$ is $\approx 7^{\circ} \mathrm{C}$.

\subsection{2. $\mathrm{COP}_{\mathrm{H}}$ Estimation Model}

For industrial and large-scale processes, multiple HP units in serial connection increase overall system efficiency, and therefore the Lorentz COP $[9,18]$ would describe more accurately the behavior of the HP configuration, since it takes into account the logarithmic mean temperature of the sink and source, as well as both inlet and outlet temperatures of the condenser and evaporator. According to 
Reinholdt et al. [18], the maximum theoretical COP of a heat pump can be estimated by calculating Lorentz COP, defined as follows:

$$
C O P_{L o r}=\frac{T_{l m, H}}{T_{l m, H}-T_{l m, L}}, \text { where } T_{l m, H}=\frac{T_{H P C, S}-T_{H P C, R}}{\ln \left(\frac{T_{H P C, S}}{T_{H P C, R}}\right)} ; T_{l m, L}=\frac{T_{H P E, O}-T_{H P E, I}}{\ln \left(\frac{T_{H P E, O}}{T_{H P E, I}}\right)}
$$

In Equation (3), $T_{l m, H}$ and $T_{l m, L}$ are, respectively, the logarithmic mean temperature of the sink and source, where notations HPC and HPE stand for heat pump's condenser and evaporator temperatures, while notations $I / O$ stand for inlet/outlet temperatures of the evaporator and $S / R$ stand for supply/return temperatures of the condenser (all values expressed in Kelvin). Based on the best industrial refrigeration systems, Reinholdt et al. [18] suggested values for Lorentz efficiency between $50 \%$ and $60 \%$ of the maximum Lorenz COP calculated with Equation (3). In our case study, a more conservative value of $45 \%$ was adopted.

\subsubsection{GSHP Utilization for District Cooling}

As mentioned previously, part of DC demand can be produced by free cooling in a first stage cooling exchanger located at the beginning of ATES pumping flow. After that, GSHP is utilized in the second place for simultaneously cooling the ATES flow in the evaporator as well as supplying heat to DH network in the condenser (see Figure 3). Finally, second stage cooling is applied, and groundwater is injected into the aquifer.

For each hour of operation, it is crucial to determine the exact aquifer pumping flow rate $Q\left[\mathrm{~m}^{3} / \mathrm{s}\right]$ since there is constraint for daily pumping of $2500 \mathrm{~m}^{3} /$ day. Due to this limitation, the maximum heat output of the GSHP condenser is limited to 1.4 and 1.6 MW in scenario 1 and 2 respectively, and pumping flow rate is calculated according to the iterative algorithm developed below.

\subsubsection{Computation of ATES Hourly Pumping Rate}

Since there are several exchangers (two and three, respectively, for scenario 1 and 2) in the ATES flow path, the minimum needed pumping flow rate is proposed to be estimated iteratively. If $\Phi_{\text {heat }, n}$ and $\Phi_{c o o l, n}$ are, respectively, heating and cooling demand to be covered in hour $n$, as the first estimation of the pumping flow can be taken the maximum flow needed either for heating or cooling (notations according to Figure 3):

$$
\begin{gathered}
\text { Step 1: } Q_{n}=\max \left\{\frac{\left(1-\frac{1}{C O P_{n}}\right) \varnothing_{\text {heat }, n}}{S_{V C, w a t}\left(T_{H P E, I, n}-T_{H P E, O, n}\right)} ; \frac{\varnothing_{c o o l, n}}{S_{V C, \text { wat }}\left(T_{H P E, I, n}-T_{A Q, A B S, n}+T_{A Q, I N J, n}-T_{H P E, O, n}\right)}\right\} \\
T_{H P E, I, n}=T_{A Q, A B S, n}(\text { in sc. } 1) ; T_{H P E, I, n}=\max \left\{T_{A Q, A B S, n} ; T_{D C, R, n}-\Delta T_{\min }\right\}(\mathrm{sc} .2) \\
T_{A Q, I N J, n, \max }=T_{D C, R, n}-\Delta T_{\min } ; T_{H P E, O, n, \min }=2 C ; S_{V C, \text { wat }}=4.19 \mathrm{MJ} / \mathrm{m}^{3} \mathrm{~K}
\end{gathered}
$$

where $\Delta T_{\min }=2{ }^{\circ} \mathrm{C}$ is the minimum pinch point difference in cooling exchangers and $\Delta T_{H P E, O, n, \min }=$ $2{ }^{\circ} \mathrm{C}$ is the minimum temperature after the GSHP evaporator. $\mathrm{COP}_{\mathrm{n}}$ is calculated with Equation (3), assuming average values for $T_{H P E, O}=10^{\circ} \mathrm{C}\left(12{ }^{\circ} \mathrm{C}\right.$ for scenario 2$), T_{H P E, O}=2{ }^{\circ} \mathrm{C}\left(3{ }^{\circ} \mathrm{C}\right.$ for scenario 2$)$. Once the first estimation for $Q_{n}$ is known, it is possible to calculate separately all exchangers within the ATES flow path, in both scenarios 1 and 2, as follows.

Scenario 1: Recalculation of temperature after HP evaporator:

$$
\text { Step 2: } T_{H P E, O, n}=T_{H P E, I, n}-\frac{\left(1-\frac{1}{C_{P} P_{n}}\right) \varnothing_{\text {heat }, n} \cdot Q_{n}}{S_{V C, w a t}}
$$

Scenario 2: Recalculation of first and second stage cooling demands:

$$
\text { Step 2: } \varnothing_{\text {cool-1stage, } n}=Q_{n} S_{V C, w a t}\left(T_{H P E, I, n}-T_{A Q, A B S, n}\right)
$$




$$
\begin{gathered}
T_{H P E, O, n}=T_{H P E, I, n}-\frac{\left(1-\frac{1}{C P_{n}}\right) \varnothing_{\text {heat }, n} \cdot Q_{n}}{S_{V C, w a t}} \\
\varnothing_{\text {cool-2stage }, n}=\min \left\{Q_{n} S_{V C, \text { wat }}\left(T_{H P E, I, n}-T_{A Q, I N J, n}\right) ; \varnothing_{\text {cool }, n}-\varnothing_{\text {cool-1stage }, n}\right\} \\
\varnothing_{\text {cool }, n}=\varnothing_{\text {cool-1stage }, n}+\varnothing_{\text {cool-2stage, } n}
\end{gathered}
$$

The ATES flow is recalculated again in Step 1, and if the new value deviates more than a predefined threshold from the previous one (in this case a $5 \%$ threshold is adopted), then the whole loop (Step $1 /$ Step 2) is repeated.

\subsubsection{Calculation of ATES Pumping Power Demand}

The required pumping power [kW] for ATES operation can be calculated on an hourly basis, assuming overall pressure drop in the line $\Delta p=600 \mathrm{kPa}$ and standard pumping efficiency $\eta=0.55$ [19], as follows:

$$
P_{A T E S, n}=\frac{Q_{n} \Delta p}{\eta}
$$

\subsubsection{Calculation of Pumping Power Demand to DH-DC Network}

Similarly, pumping power $[\mathrm{kW}]$ to provide DH-DC through the GSHP condenser/evaporator respectively can be calculated hourly, assuming overall pressure drop between supply and return lines $\Delta p_{D H}=\Delta p_{D C}=250 \mathrm{kPa}[20]$ and standard pumping efficiency $\eta=0.55$ [21], as follows:

$$
P_{H P C-t o-D H, n}=\frac{Q_{H P C, n} \Delta p_{D H}}{\eta} ; P_{H P E-t o-D C, n}=\frac{Q_{H P E, n} \Delta p_{D C}}{\eta}
$$

where

$$
Q_{H P C, n}=\frac{\varnothing_{\text {supplied-heat }, n}}{S_{V C, \text { wat }}\left(T_{H P C, S, n}-T_{D H, R, n}\right)} ; Q_{H P E, n}=\frac{\varnothing_{\text {cool-1stage }, n}+\varnothing_{\text {cool-2stage }, n}}{S_{V C, \text { wat }}\left(T_{D C, R, n}-T_{D C, S, n}\right)}
$$

The volumetric heat capacity of water $S_{V C, \text { wat }}$ used was 4.19 and $4.1 \mathrm{MJ} / \mathrm{m}^{3} \mathrm{~K}$, respectively, for cooling and heating operation.

\subsubsection{Numerical Model and Its Calibration for Steady State}

The groundwater model is set up utilizing the finite difference code MODFLOW [12] with ModelMuse environment [22]. In ModelMuse, the aquifer is discretized with a $100 \times 100 \mathrm{~m}$ square cell grid, covering a physical extension of about $20 \mathrm{~km}^{2}$, delimited between the Aura River to the northwest and the Baltic Sea to the southwest. Southeast and northeast borders are assumed as no-flow boundaries (see Figure 4).

Groundwater model calibration for steady state was carried out taking into account the long-term statistical data for 15 observation wells in the Kupittaa area and eight observation wells in Kaarninko. Calibration was done according to the procedure developed by Todorov et al. [23], by using root mean squared error (RMSE) [24] and mean absolute error (MAE) [25] for the close field (Kupittaa) and far field (Kaarninko). As seen in Figure 5, the results of Kaarninko (far-field area) were more dispersed (calculated RMSE $=1.32 \mathrm{~m} / \mathrm{MAE}=1.07 \mathrm{~m}$ ), since our model is intended to present better correlation between measured and simulated values (RMSE $=0.54 \mathrm{~m} / \mathrm{MAE}=0.29 \mathrm{~m}$ ) within the close-field calibration. In most of Kupittaa's observation wells, this difference was within the margins of the measured long-term standard deviation. A typical horizontal hydraulic conductivity for sand/gravel aquifer was selected: $K=5 \times 10^{-5} \mathrm{~m} / \mathrm{s}$ (Luoma [26]), and during model calibration was adjusted to $5 \times 10^{-4} \mathrm{~m} / \mathrm{s}$ for the area containing the observation wells (small black rhombs in Figure 4 delimited by circles). The value of vertical hydraulic conductivity was chosen as $K_{z}=0.1 \mathrm{~K}$. Typical values were also utilized for storativity $\left(S=1 \times 10^{-5}\right)$, porosity $(n=0.25)$ and recharge rate of $R=1.3 \times 10^{-8} \mathrm{~m} / \mathrm{s}$ [26]. 


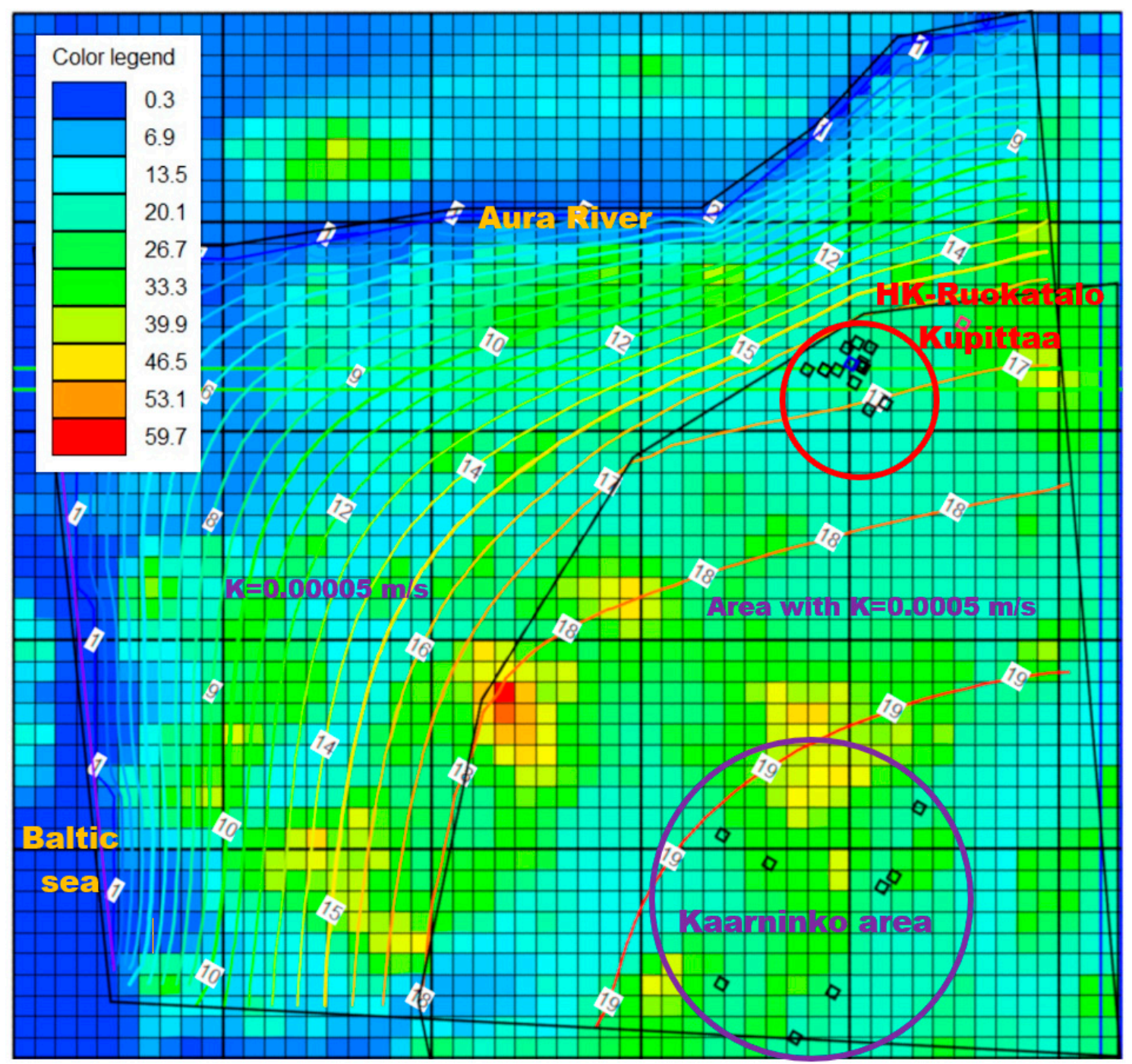

Figure 4. Numerical model and steady state solution (ModelMuse).

In Figure 4, the calibrated groundwater model and its steady state solution are depicted, where iso-lines represent groundwater head in meters while the color grid represent elevation between blue (min. elevation, $0.3 \mathrm{~m}$ above sea level) and red (max. elevation $59.6 \mathrm{~m}$ ). As seen in Figure 4 , the natural groundwater flow moves from the Kaarninko area (highest hydraulic heads 19-20 m) towards the Kupittaa area (hydraulic heads 16-17 m), and finally reaches the lowest hydraulic boundaries represented by the Aura River and Baltic Sea. 


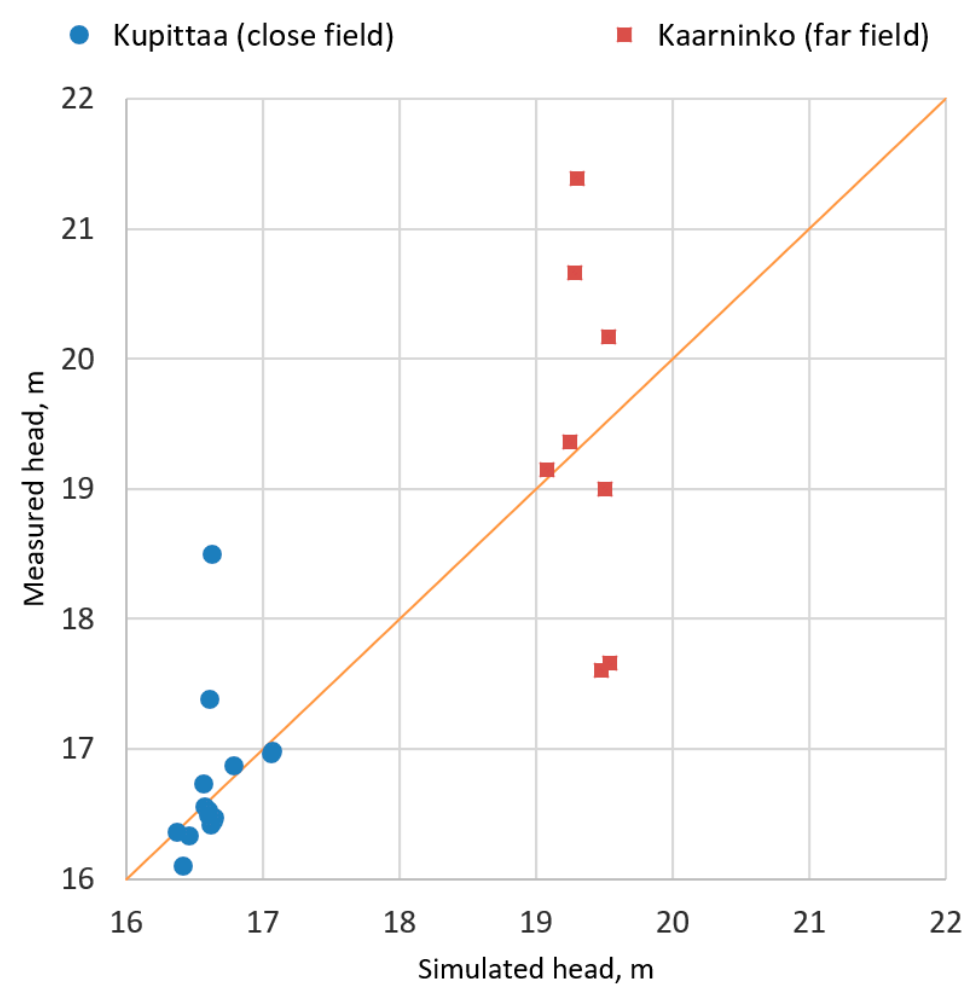

Figure 5. Groundwater model calibration.

\subsection{Technoeconomic Evaluation of GSHP-ATES}

Based on hourly calculations, different technical variables are computed, like the annual energy generation for heating/cooling, the electricity consumption and the average daily ATES pumping rate. Table 2 lists the relevant ATES technical variables.

Table 2. Technical variables of ATES.

\begin{tabular}{ccc}
\hline Variables & Units & Comments \\
\hline GSHP supply temperature & ${ }^{\circ} \mathrm{C}$ & Depending on demanded power fraction, Equation (1) \\
\hline GSHP COP & - & Depending on GSHP source and sink temperatures, Equation (3) \\
\hline ATES flow rate $Q$ & $\mathrm{~m}^{3} / \mathrm{s}$ & Calculated according to the algorithm exposed in 2.3.2 \\
\hline GSHP electric power demand & $\mathrm{MW}$ & Based on HP heat load covered and COP \\
\hline $\begin{array}{c}\text { Electric power demand for } \\
\text { ATES pumping }\end{array}$ & $\mathrm{kW}$ & $\begin{array}{c}\text { Based on the computed flow rate } Q \text {, assumed pressure drop and } \\
\text { efficiency (Equation (4)) }\end{array}$ \\
\hline $\begin{array}{c}\text { Electric power demand for } \\
\text { DH-DC pumping }\end{array}$ & $\mathrm{kW}$ & $\begin{array}{c}\text { Based on the computed flow rate for each network, assumed } \\
\text { pressure drop and efficiency (Equation (5)) }\end{array}$ \\
\hline Daily ATES flow rate & $\mathrm{m}^{3} / \mathrm{day}$ & Average daily ATES flow rate \\
\hline Annual heating demand & $\mathrm{MWh}$ & Heating demand covered by GSHP \\
\hline Annual cooling demand & $\mathrm{MWh}$ & Cooling demand covered by ATES system (first/second stage) \\
\hline Annual GSHP demand & $\mathrm{MWh}$ & Electricity demand of GSHP \\
\hline Annual pumping demand & $\mathrm{MWh}$ & Pumping demand of ATES, DH and DC operation \\
\hline
\end{tabular}

A cost database regarding various energy generation technologies was used (after Nielsen et al. $[27,28]$ ), as well as prices for ATES well drilling, heat exchangers, and piping (Drenkelfort et al. [29]) for estimating the investment cost. Based on the annuity method, the energy generation cost is calculated, assigning annual investment payments (annuity) and assuming 5\% interest rate as well as the investment lifetime of 20 years (Nielsen et al. [27]). The operation and maintenance (O\&M) costs ( $1 \%$ of investment) are also included within the overall annual cost, as well as the electricity cost for 
GSHP and pumping (given electricity price of $100 € / \mathrm{MWh}$, including taxes, transfer and distribution fees [30]). The economic evaluation was developed according to Todorov et al. [23], including the calculation of the following variables listed in Table 3.

Table 3. Variables for economic evaluation.

\begin{tabular}{ccc}
\hline Variables & Units & Comments \\
\hline Overall investment cost & $€$ & Geological survey, cost of GSHP, exchangers, drilling and piping \\
\hline Annuity factor & - & Computed for 20 years lifetime and 5\% interest rate \\
\hline Investment cost (annuity) & $€$ & Calculated as overall investment cost times annuity factor \\
\hline Fixed annual O\&M costs & $€$ & $1 \%$ of overall investment cost \\
\hline Electricity annual cost & $€$ & Electricity cost of GSHP and pumping \\
\hline Overall annual cost & $€$ & Annuity + O\&M costs + electricity cost \\
\hline Specific energy cost & $€ /$ MWh & Overall annual cost per total thermal energy generation \\
\hline
\end{tabular}

\section{Results and Discussion}

\subsection{Technoeconomic Analysis}

The main technical parameters of ATES operation for both studied scenarios are shown in Table 4. It can be acknowledged that even with $5 \%-6 \%$ of peak heat power for scenario 1 and 2 , the GSHP coverage ratio is $18 \%-20 \%$ of the annual heating demand. Moreover, an important advantage of scenario 2 is shown when comparing a cooling demand covered by ATES. The scheme with two cooling exchangers in scenario 2 allows 78\% coverage of DC demand annually (compared to $67 \%$ in scenario 1), from which the first stage cooling represents roughly one sixth.

Table 4. ATES system technical parameters.

\begin{tabular}{|c|c|c|c|c|c|c|}
\hline \multirow{2}{*}{$\begin{array}{l}\text { Relevant Parameters of ATES Operation } \\
\text { Annual/seasonal results for scenarios } 1 / 2\end{array}$} & \multicolumn{2}{|c|}{ Annually } & \multicolumn{2}{|c|}{ Summer } & \multicolumn{2}{|c|}{ Winter } \\
\hline & Sc. 1 & Sc. 2 & Sc. 1 & Sc. 2 & Sc. 1 & Sc. 2 \\
\hline ATES period duration, weeks & 52 & 52 & 26 & 26 & 26 & 26 \\
\hline Pre-cooling/heating/cooling power, MW & $-/ 1.43 / 1$ & $0.3 / 1.63 / 1.3$ & - & - & - & - \\
\hline Average water flow, $\mathrm{m}^{3} /$ day & 2492 & 2496 & 2452 & 2559 & 2531 & 2434 \\
\hline Average abstraction temperature, ${ }^{\circ} \mathrm{C}$ & 10.0 & 10.0 & 10.0 & 10.0 & 10.0 & 10.0 \\
\hline Average injection temperature, ${ }^{\circ} \mathrm{C}$ & 10.0 & 10.0 & 10.4 & 11.0 & 9.5 & 8.9 \\
\hline Average temperature before $\mathrm{GSHP},{ }^{\circ} \mathrm{C}$ & 10.0 & 11.5 & 10.0 & 11.5 & 10.0 & 11.6 \\
\hline Average temperature after $\mathrm{GSHP},{ }^{\circ} \mathrm{C}$ & 2.1 & 2.5 & 2.2 & 3.0 & 2.0 & 2.0 \\
\hline Average GSHP supply temperature, ${ }^{\circ} \mathrm{C}$ & 65.4 & 66.5 & 68.1 & 69.3 & 62.6 & 63.8 \\
\hline Average $\mathrm{DH}$ return temperature, ${ }^{\circ} \mathrm{C}$ & 40.9 & 40.9 & 40.5 & 40.5 & 41.4 & 41.4 \\
\hline Average GSHP COP (heating mode) & 3.14 & 3.21 & 3.08 & 3.14 & 3.20 & 3.27 \\
\hline Heating demand, MWh & \multicolumn{2}{|c|}{67,971} & \multicolumn{2}{|c|}{16,761} & \multicolumn{2}{|c|}{51,210} \\
\hline Heat demand covered by GSHP, MWh & 12,315 & 13,882 & 6034 & 6723 & 6281 & 7159 \\
\hline Heating demand covered by GSHP, \% & $18 \%$ & $20 \%$ & $36 \%$ & $40 \%$ & $12 \%$ & $14 \%$ \\
\hline Cooling demand, MWh & \multicolumn{2}{|c|}{12,382} & \multicolumn{2}{|c|}{7944} & \multicolumn{2}{|c|}{4439} \\
\hline First stage cooling covered, MWh & - & 1605 & - & 780 & - & 825 \\
\hline Second stage cooling covered, MWh & 8331 & 8006 & 4279 & 4454 & 4052 & 3551 \\
\hline Total cooling demand covered, MWh & 8331 & 9611 & 4279 & 5234 & 4052 & 4377 \\
\hline Total cooling demand covered, $\%$ & $67 \%$ & $78 \%$ & $54 \%$ & $66 \%$ & $91 \%$ & $99 \%$ \\
\hline Electricity demand (GSHP), MWh & 3934.2 & 4334.5 & 1964.4 & 2138.9 & 1969.8 & 2195.6 \\
\hline Electricity demand (ATES pump.), MWh & 275.6 & 276.1 & 135.2 & 141.1 & 140.4 & 134.9 \\
\hline Electricity demand (HP-DH pump.), MWh & 57.7 & 62.1 & 24.8 & 26.5 & 33.0 & 35.7 \\
\hline Electricity demand (HP-DC pump.), MWh & 130.7 & 150.5 & 66.6 & 81.3 & 64.1 & 69.3 \\
\hline Total electricity demand, MWh & 4398.2 & 4823.2 & 2191.0 & 2387.7 & 2207.2 & 2435.5 \\
\hline
\end{tabular}


The estimation of economic feasibility parameters and the production cost of thermal energy are shown in Tables 5 and 6 respectively. The resulting thermal energy production cost in scenario 2 is slightly below $30 € / \mathrm{MWh}$. Overall investment cost is around 2.3 million $€: 26 \%$ corresponds to GSHP/exchangers and 73\% is related to the underground components (connection pipes and wells), figures close to similar ATES realization in Germany (Schüppler et al. [31]). The specific investment cost per installed heat pump capacity is $1.6 / 1.4 € / \mathrm{W}$ for scenario 1 and 2 respectively, values comparable to the $1.8 € / \mathrm{W}$ reported for a similar ATES system in a Belgian hospital (Vanhoudt et al. [32]).

Table 5. Economic parameters of GSHP-ATES.

\begin{tabular}{cccccc}
\hline Investment Cost. & Price & Sc. 1 (Units) & Sc. 2 (Units) & Total Scenario 1 & Total Scenario 2 \\
\hline $\begin{array}{c}\text { Subsurface study, geological } \\
\text { report and pumping tests, } € / \mathrm{u}\end{array}$ & 30,000 & 1 & 1 & 30,000 & 30,000 \\
\hline Ground-source heat pump, $€ / \mathrm{kW}$ & 300 & 1.43 & 1.63 & 429,000 & 489,000 \\
\hline Heat exchangers, $€ / \mathrm{kW}$ & 35 & 2.43 & 3.23 & 85,050 & 113,050 \\
\hline $\begin{array}{c}\text { Pumping well (including } \\
\text { equipment and pump), } € / \mathrm{u}\end{array}$ & 170,000 & 8 & 8 & $1,360,000$ & $1,360,000$ \\
\hline Connection pipes, $€ / \mathrm{m}$ & 250 & 1300 & 1300 & 325,000 & 325,000 \\
\hline \multicolumn{7}{c}{ Overall investment cost, $€$} \\
\hline
\end{tabular}

Table 6. Energy production cost.

\begin{tabular}{ccc}
\hline Annuity Method & Scenario 1 & Scenario 2 \\
\hline Annuity factor (interest rate 5\%, 20 years lifetime) & \multicolumn{2}{c}{0.0802} \\
\hline Investment cost (annuity), $€$ & $178,865 €$ & $185,786 €$ \\
\hline Fixed annual O\&M cost, $€$ & $22,291 €$ & $23,153 €$ \\
\hline Electricity annual cost, $€$ & $439,820 €$ & $482,324 €$ \\
\hline Overall annual cost, $€$ & $640,976 €$ & $691,263 €$ \\
\hline Specific energy cost, $€ / \mathrm{MWh}$ & $31.05 € / \mathrm{MWh}$ & $29.43 € / \mathrm{MWh}$ \\
\hline
\end{tabular}

Additionally, scenario 2 is investigated with more details, as follows. GSHP COP is 3.2 on average, slightly improving to 3.3 during the winter due to lower GSHP supply temperature ( $64{ }^{\circ} \mathrm{C}$ on average), while, during the summer, GSHP covers a higher heat fraction and the average supply temperature increases to $69^{\circ} \mathrm{C}$ (see Figure 6).

ATES operation is based on energy conversion using electricity to cogenerate heating and cooling in a single operation. GSHP is the principal electricity consumer accounting for $90 \%$ of the annual demand, followed by ATES pumping $(6 \%)$ as well as pumping needed to inject HP supply energy to DH-DC networks-respectively $1 \%$ and $3 \%$. This is important to acknowledge since total electricity demand $(4.8 \mathrm{GWh} / \mathrm{a})$ has a significant impact on the annual cost, and, consequently, on the specific cost of generated heating and cooling energy, as seen in Table 6. The ATES system is well balanced, as seen from the average injection and abstraction temperatures that are both equal to the aquifer's undisturbed temperature of $10{ }^{\circ} \mathrm{C}$. Moreover, the system is balanced in terms of energy, as shown in Table 4, since the annual heat demand covered is equal to cooling demand covered plus GSHP power demand $(13.9 \mathrm{GWh})$. Figure 7 depicts the annual variation of all temperatures along the ATES flow path: abstraction, after first stage cooling, after GSHP evaporator, and finally injection. 


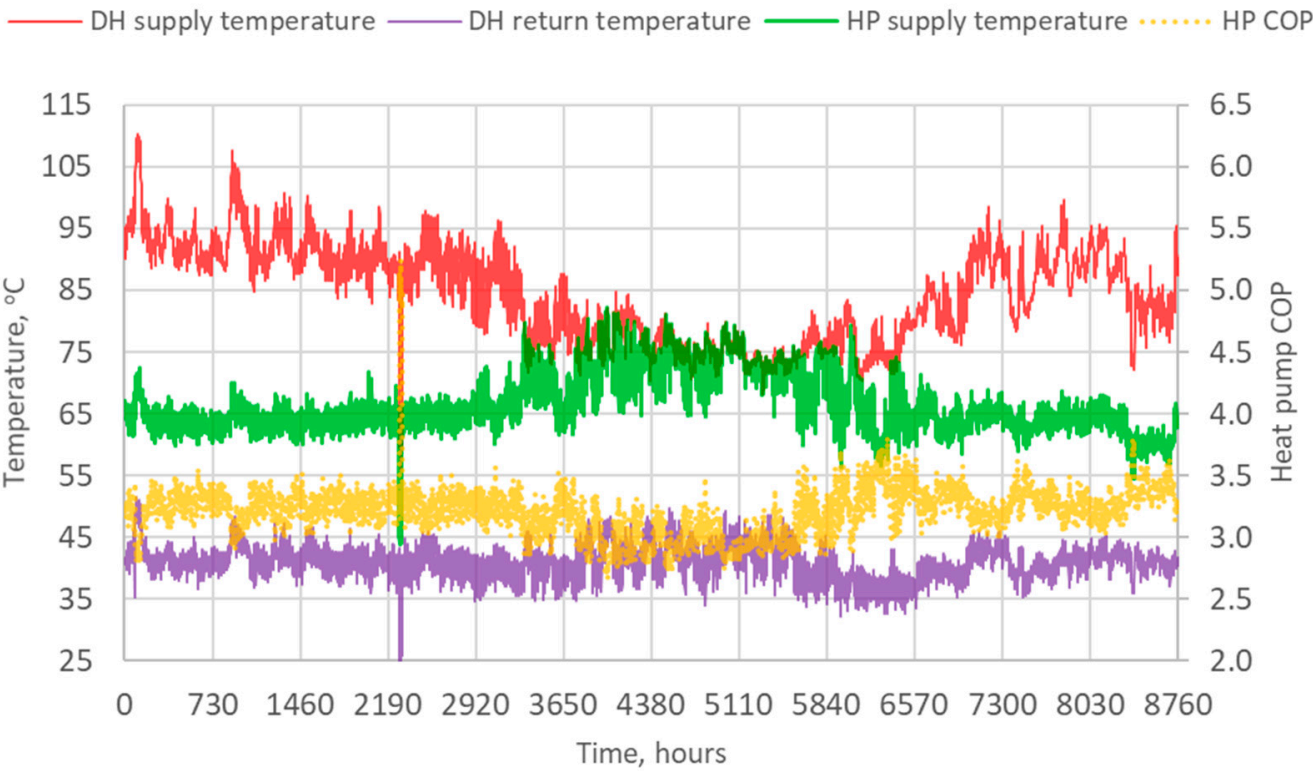

Figure 6. Annual evolution of DH-GSHP network temperatures in scenario 2.

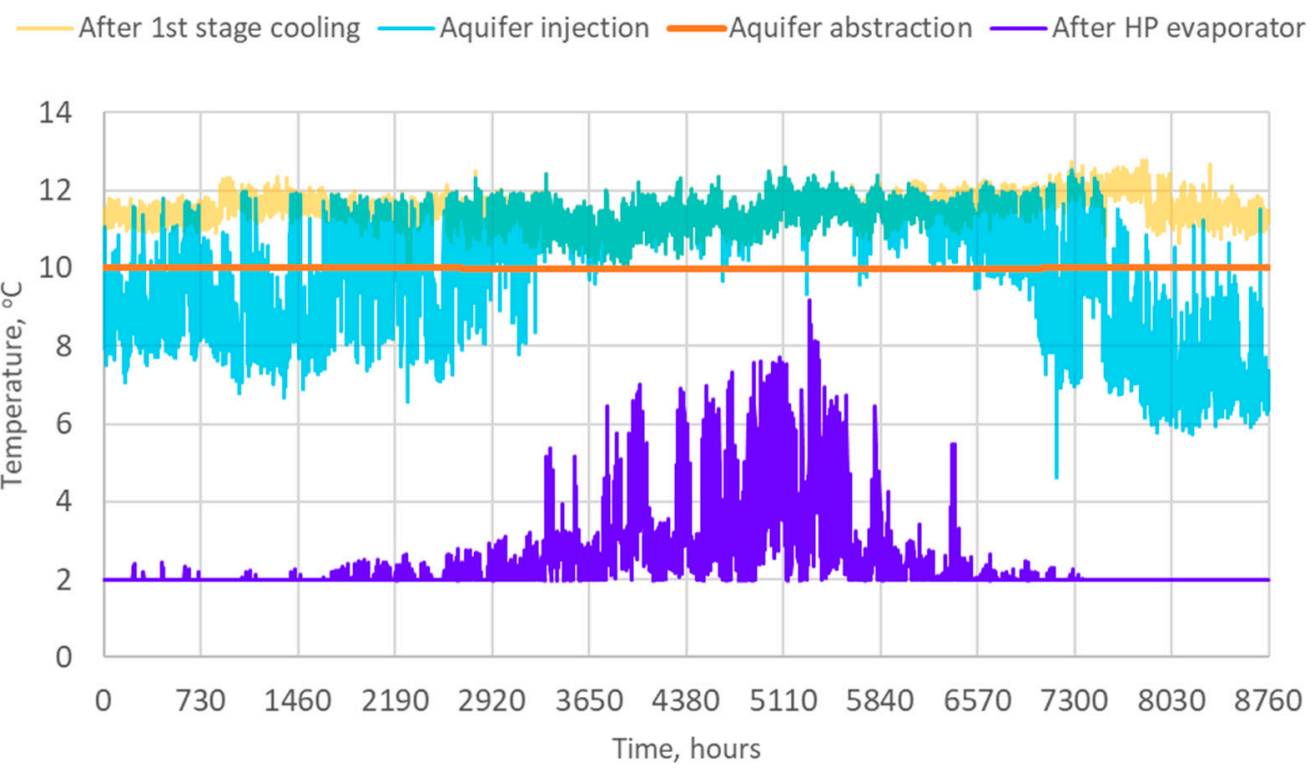

Figure 7. Annual evolution of ATES temperatures.

\subsection{Sensitivity Analysis of the System's Operation}

As shown in Table 6, about 70\% of energy production cost is related to electricity consumption, of which the GSHP accounts for around 90\%. The heat pump's COP is an important variable to consider in order to boost the system's efficiency and decrease cost. That is why, in this section, a sensitivity analysis will be performed regarding COP and energy production cost, and how they depend on the exponent parameter $p$. The effect of varying $p$ within the interval [0;1] is that, e.g., for $p=1$, flow recirculated through GSHP condenser is directly proportional to power fraction $k$, and thus heat pump supply temperature should be equal to DH supply temperature. Figure 8 plots a $\Delta T_{H P C} / \Delta T_{D H}$ fraction of GSHP condenser calculated with Equation (1) and a temperature drop fraction after heat pump junction $\Delta T_{D H, S} / \Delta T_{D H}$ calculated with Equation (2) for different values of $p=0.2,0.4,0.6,0.8$. The comparative thermal effect for $\Delta T_{D H}=40^{\circ} \mathrm{C}$ is illustrated in the secondary vertical axis. From Figure 8, it can be seen that, for lower values of $p$, the GSHP has higher efficiency when working at lower power fractions (e.g., during the winter period) since HP supply temperature is not so high as 
DH supply. The drawback is that, after HP junction, DH supply temperature $T_{D H, S 2}$ can also present an important temperature drop $\Delta T_{D H, S}$ (e.g., red dashed curve, for $p=0.2$ ). It is also interesting to explore what is the maximum $\Delta T_{D H, S}$ for each $p$ within the interval [0;1]. Let's define the following function $f(k)$, as the ratio between $\Delta T_{D H, S}$ and $\Delta T_{D H}$, according to Equation (2):

$$
f(k)=k^{p}-k \Rightarrow f^{\prime}(k)=\frac{d f}{d k}=p k^{p-1}-1
$$

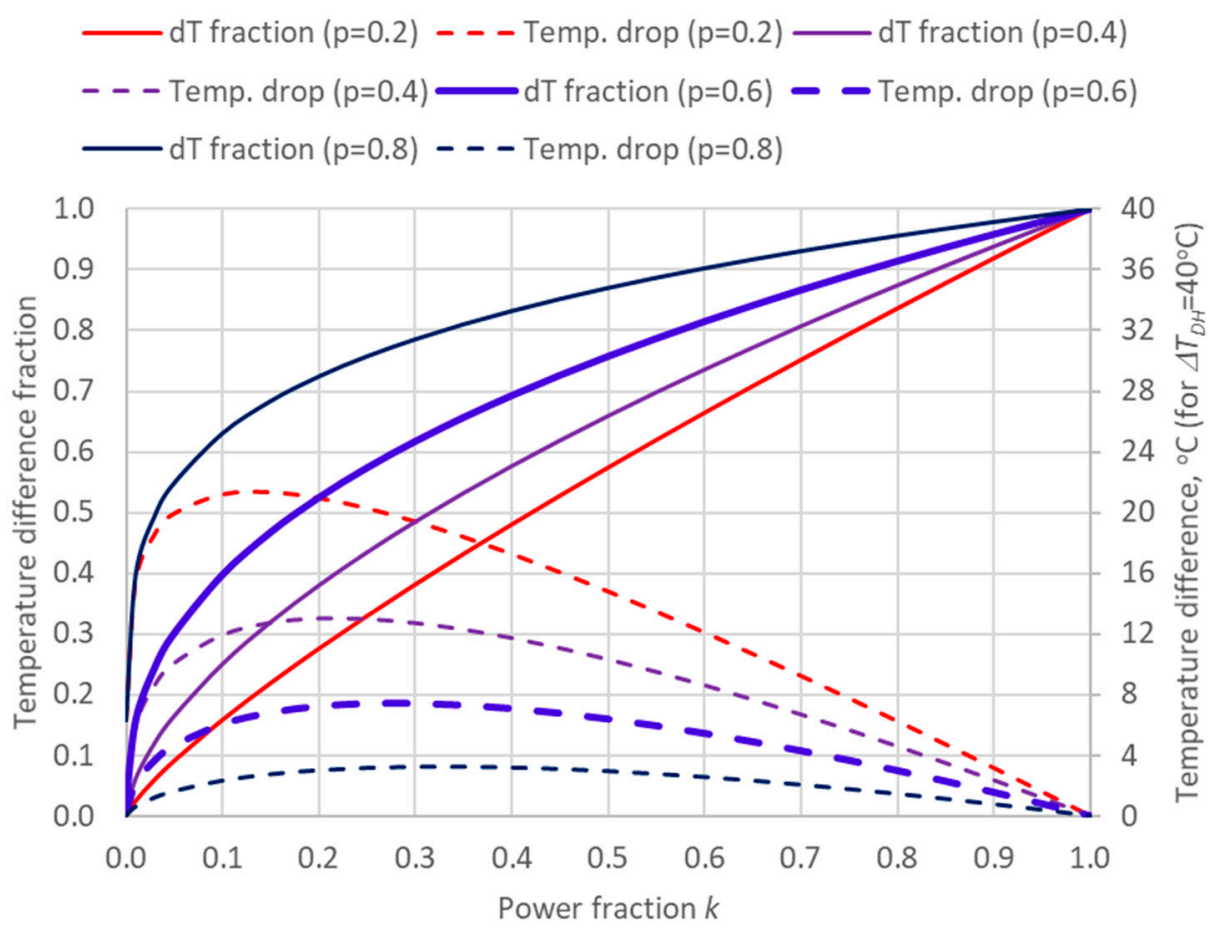

Figure 8. Temperature difference (dT) fraction $\Delta T_{H P C} / \Delta T_{D H}$ and temperature drop fraction after HP junction $\left(\Delta T_{D H, S} / \Delta T_{D H}\right)$.

As seen from Figure 8, in the interval $[0 ; 1], f(k)$ has one maximum, which can be found where the function's first derivative is zero:

$$
0=f^{\prime}(k)=p k^{p-1}-1 \Leftrightarrow p k^{p-1}=1 \Rightarrow k_{\max }=p^{\frac{1}{1-p}} \Rightarrow f_{\max }=f\left(k_{\max }\right)=p^{\frac{p}{1-p}}-p^{\frac{1}{1-p}}=p^{\frac{1}{1-p}}\left(p^{-1}-1\right)
$$

Similarly, it is possible to calculate the average value of $f(k)$ within $[0 ; 1]$ as:

$$
f_{a v g}=\int_{0}^{1} f(k)=\int_{0}^{1} k^{p}-k=\frac{1}{1+p}-\frac{1}{2}
$$
Figure 9.

The results for $f_{\max }$ and $f_{\text {avg }}$ calculated respectively with Equations (8) and (9) are presented in 


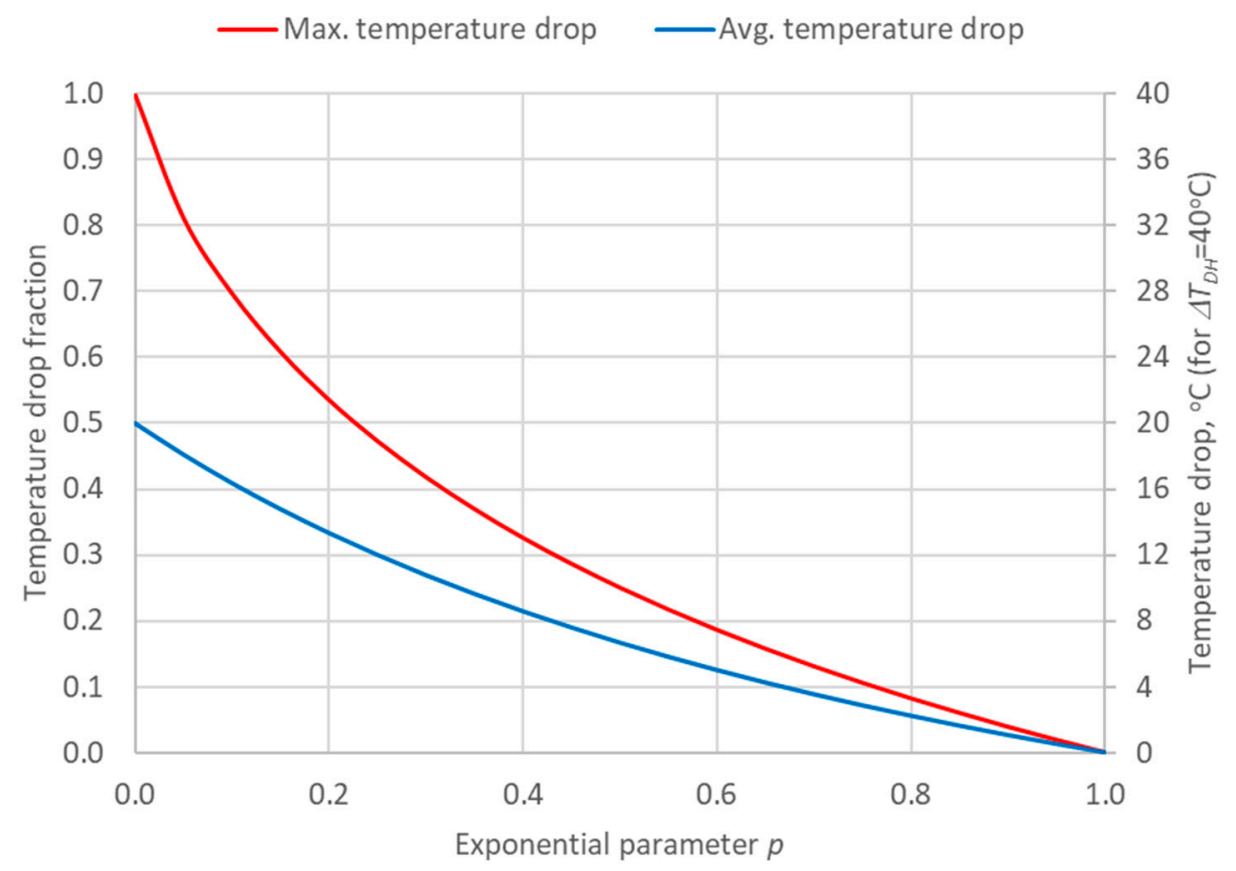

Figure 9. Maximum and average values for $\mathrm{f}$ function.

As previously noticed, and also presented in Figures 8 and 9, for low values of $p$, the temperature drop after HP junction can increase significantly. Moreover, when $p=0.2$, for the maximum and average temperature drop, the fraction is as high as 0.53 and 0.33 of $\Delta T_{D H}$ respectively, while for $p=0.8$ the possible gains in low power fraction are quite limited. Therefore, a sensitivity analysis for scenario 2 was performed, for four different values of $p$ :

- $\quad$ Case 1: $p=0.2$

- $\quad$ Case 2: $p=0.4$

- $\quad$ Case 3: $p=0.6$ (base case, blue thick curves in Figure 8)

- $\quad$ Case 4: $p=0.8$

All cases are simulated on an hourly basis, with the same constraint for ATES average daily pumping flow, and the annual results are listed in Table 7. By decreasing $p$, the average GSHP supply temperature also decreases, while the average COP increases, and vice versa. From Table 7, it also can be seen that the higher the COP, the lower GSHP heat capacity needed, since the fraction supplied by the HP compressor is lower. The latter also explains why the annual heat demand covered is lower for high COP, while the annual cooling demand covered remains stable among the four cases.

The percentage variations compared to the base case 3 are plotted in Figure 10. It is important to notice how the energy production cost decreases as COP increases. On the other hand, an important drawback for cases 1 and 2 is the high temperature drop in DH supply temperature, $19.1^{\circ} \mathrm{C}$ and $11.6^{\circ} \mathrm{C}$ respectively, which is a confirmation that case 3 is a reasonable trade-off between the system's efficiency, economic feasibility, and technical constraints. 
Table 7. Sensitivity analysis based on four cases (case 3 is the base case).

\begin{tabular}{ccccc}
\hline Relevant ATES Parameters. & C1: $p=\mathbf{0 . 2}$ & C2: $p=\mathbf{0 . 4}$ & C3: $\boldsymbol{p = 0 . 6}$ & C4: $\boldsymbol{p}=\mathbf{0 . 8}$ \\
\hline Peak pre-cooling/heating/cooling power, MW & $0.3 / 1.57 / 1.3$ & $0.3 / 1.6 / 1.3$ & $0.3 / 1.63 / 1.3$ & $0.3 / 1.7 / 1.34$ \\
\hline Annual heat demand supplied by GSHP, MWh & 13,418 & 13,650 & 13,882 & 14,419 \\
\hline Annual cooling demand supplied, MWh & 9551 & 9577 & 9611 & 9659 \\
\hline Average GSHP supply temperature, ${ }^{\circ} \mathrm{C}$ & 57.2 & 61.1 & 66.5 & 74.1 \\
\hline Average GSHP COP (heating mode) & 3.53 & 3.38 & 3.21 & 3.00 \\
\hline Average drop in DH supply temperature, ${ }^{\circ} \mathrm{C}$ & 19.1 & 11.6 & 6.4 & 2.7 \\
\hline Cost per MWh of heating/cooling energy & $27.99 €$ & $28.56 €$ & $29.43 €$ & $30.77 €$ \\
\hline
\end{tabular}

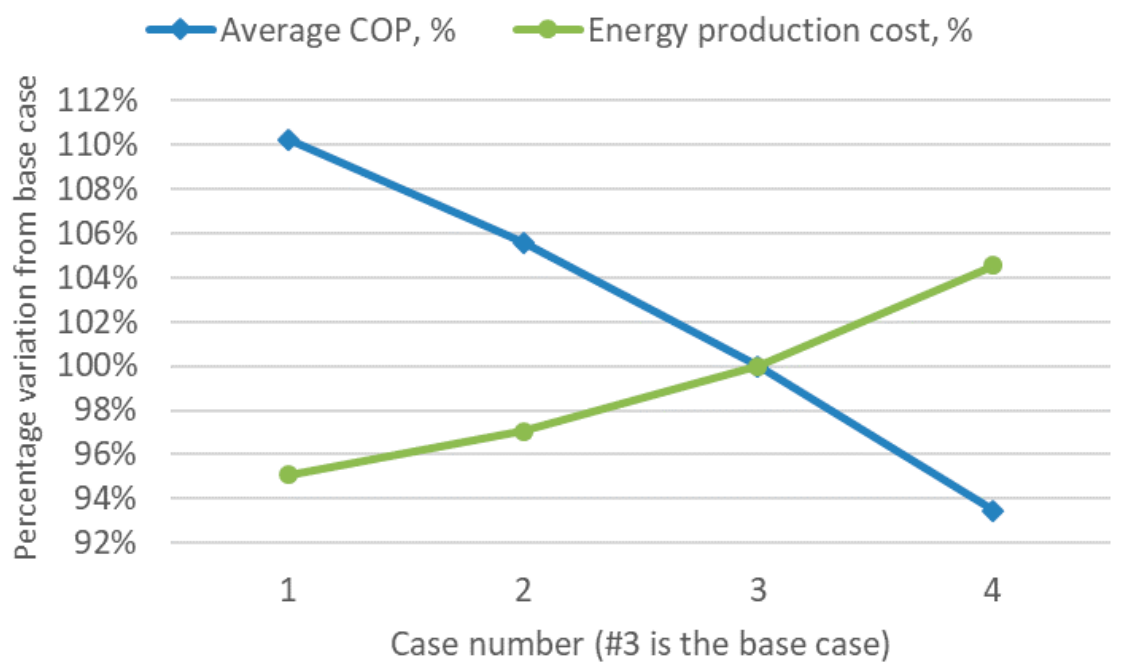

Figure 10. Sensitivity analysis: GSHP efficiency (COP) and energy production cost.

\subsection{Impact on Groundwater Areas}

Although the undisturbed aquifer temperature is as high as $10^{\circ} \mathrm{C}$, first stage cooling can be used in 8736 out of $8760 \mathrm{~h}$, and annually it represents $17 \%$ of cooling demand covered by ATES (about one sixth of $9.6 \mathrm{GWh}$ ). This configuration also increases the temperature before GSHP evaporator by $1.5^{\circ} \mathrm{C}$ on average, which improves the $\mathrm{COP}$ and enhances the heat pump's capacity in the evaporator as well. The average injection temperature lies in a narrow range of roughly $10 \pm 1^{\circ} \mathrm{C}$ (see Table 4 ), which justifies one-way ATES operation and, consequently, the thermal impact on the aquifer remains very limited.

The long-term hydraulic impact was simulated in MODFLOW by taking a weekly-based average for ATES pumping rate and defining $52 \times 20=1040$ stress periods. The result after 20 years of one-way operation is presented in Figure 11, where hydraulic head is represented by iso-lines with resolution of $0.25 \mathrm{~m}$. In order to mitigate the hydraulic impact of pumping, the injection well is placed downstream while the abstraction well is located upstream (Figure 11). The maximum simulated drawdown is 1.28 and $1.17 \mathrm{~m}$ for summer and winter operation respectively, which corresponds to 5.0 and $4.7 \mathrm{~m}$ inside the pumping well. The overall impact of ATES pumping vanishes at about $500 \mathrm{~m}$ from each well, thus it does not affect the surrounding groundwater areas in a significant way. 


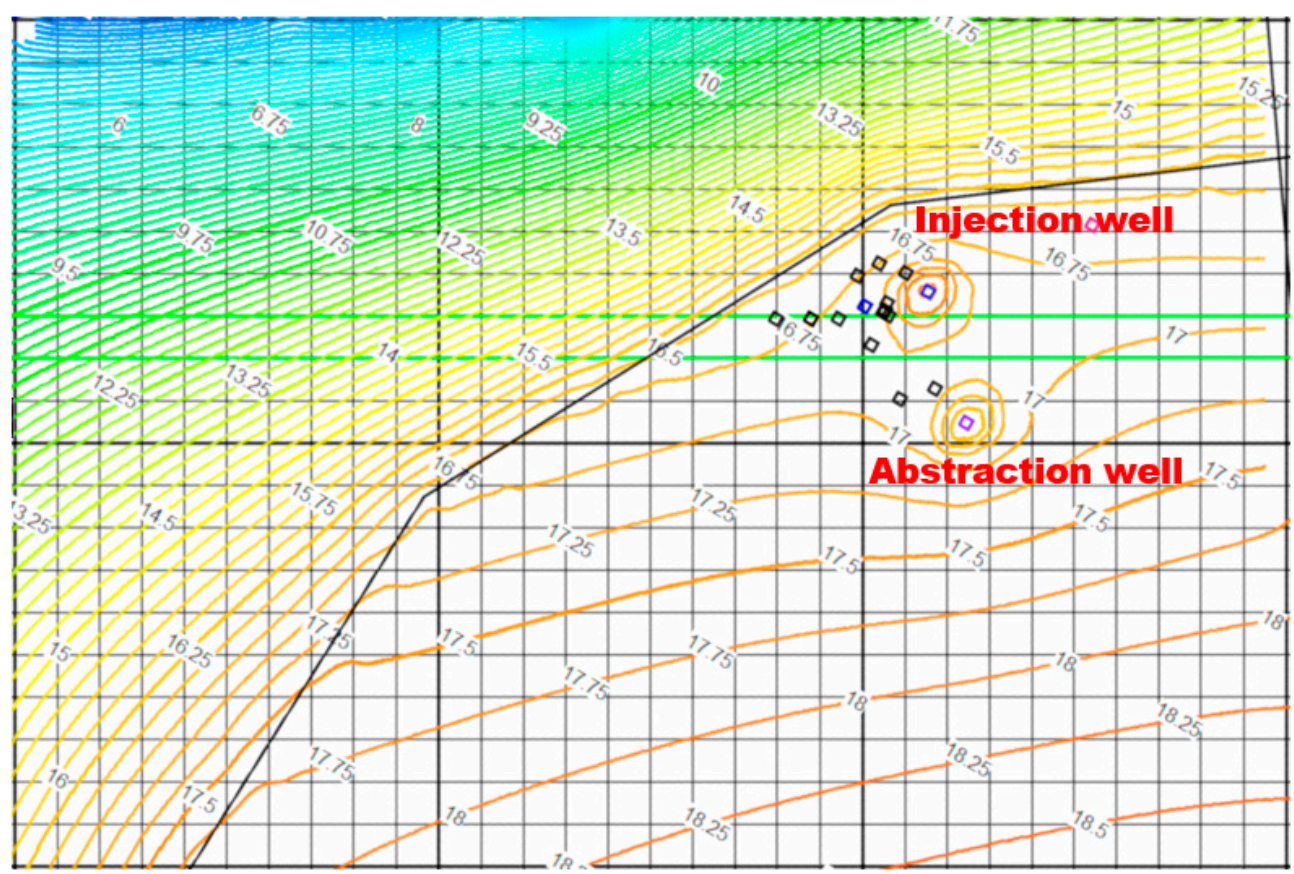

Figure 11. Hydraulic impact after 20 years of ATES operation in scenario 2.

\section{Conclusions}

The presented case study was successful in demonstrating and developing a mathematical model for system's management: calculation of HP recirculation flow, estimation of heat pump COP, as well as an algorithm for computation of ATES pumping flow rate based on the capacity to cover heating and cooling demand in a single operation. Additionally, the system's technoeconomic feasibility, efficiency, and the impact of GSHP-ATES operation on the nearby aquifer were evaluated. The groundwater model was developed and calibrated, utilizing different available data sources like the National Land Survey of Finland (NLSF), Finnish Environment Institute (SYKE), Geological Survey of Finland (GTK) and different tools such as MS Excel, QGIS and MODFLOW.

The dispatch of combined heating and cooling loads using annual data for an existing urban district in Finland was developed in tandem with the GSHP-ATES model. It presented an attractive economic outcome-competitive energy production cost around $30 € / \mathrm{MWh}$, far below $76.7 € / \mathrm{MWh}$, which was the average Finnish DH price in 2017 [33], as well as very limited long-term environmental impact on the nearby aquifer. The maximum drawdown within the pumping well was estimated as $5 \mathrm{~m}$ after 20 years of operation, and the overall hydraulic impact is limited to $500 \mathrm{~m}$ around the wells. Injection temperature deviates from undisturbed aquifer temperature at a level of about $1{ }^{\circ} \mathrm{C}$ on average, which is within the limits of Swiss $\left(3^{\circ} \mathrm{C}\right)$ and French $\left(11^{\circ} \mathrm{C}\right)$ legislation. Additional sensitivity analysis revealed that, by varying HP recirculation flow parameter (exponent parameter $p$ ), it is possible to influence the heat pump's COP and the energy production cost. However, the only constraint to be considered is the temperature drop after the HP junction in the DH supply line, which in the base case resulted in $6.4^{\circ} \mathrm{C}$ on average. The future transition to low district heating networks (Guzzini et al. [34]) by the introduction of heat pumps can eventually benefit from the proposed mathematical methodology due to its capability to find a trade-off between the energy production cost and the maximum allowed temperature drop introduced by the heat pump in the DH supply line.

The environmental assessment presented in this work was carried out using available hydrogeological data of the investigated groundwater area. The lack of reliable hydrogeological information at the present prefeasibility stage was a significant constraint for simplifying the groundwater model - the aquifer was assumed as uniform, isotropic and confined to the considered domain, and model calibration was performed only for steady state. Additional pumping tests and more detailed geological exploration would be needed as future steps. 
Overall, ATES-GSHP systems prove to be a sustainable and efficient alternative to traditional thermal energy generation based primarily on fossil fuels, due to their ability to recycle heating and cooling loads using the subsurface as practically unlimited thermal storage. By dispatching annually balanced heating and cooling loads within integrated urban energy networks, major economic and technical improvements can be accomplished.

Author Contributions: Conceptualization, O.T.; methodology, O.T.; software, O.T.; validation, O.T.; formal analysis, O.T.; investigation, O.T.; resources, O.T. and K.A.; data curation, O.T.; writing — original draft preparation, O.T.; writing-review and editing, O.T. and K.A.; visualization, O.T.; supervision, R.K.; project administration, M.V.; funding acquisition, R.K. and M.V. All authors have read and agreed to the published version of the manuscript.

Funding: This research was funded by Business Finland, grant number 8199/31/2018. The APC was funded by Aalto University, OA Fund.

Acknowledgments: This research was carried out as part of the Smart Otaniemi Project (Aalto University) and was funded by Business Finland. Special thanks to all the team of Global EcoSolutions, Finland.

Conflicts of Interest: The authors declare no conflict of interest.

\section{Nomenclature}

$\begin{array}{ll}\Phi[\mathrm{W}] & \text { Heating/cooling loads } \\ H[\mathrm{~m}] & \text { Hydraulic head } \\ K[\mathrm{~m} / \mathrm{s}] & \text { Hydraulic conductivity } \\ K[-] & \text { Power fraction between covered and demanded DH load } \\ P[\mathrm{~W}] & \text { Power demand (pumping) } \\ P[-] & \text { Exponent parameter } \\ Q\left[\mathrm{~m}^{3} / \mathrm{s}\right] & \text { ATES pumping flow rate } \\ R[\mathrm{~m} / \mathrm{s}] & \text { Aquifer recharge } \\ \mathrm{S}- & \text { Aquifer storativity } \\ S_{V C, \text { wat }}\left[\mathrm{J} / \mathrm{m}{ }^{3} \mathrm{~K}\right] & \text { Water volumetric heat capacity } \\ T_{D H, S}\left[{ }^{\circ} \mathrm{C}\right] & \text { District heating supply temperature } \\ T_{D H, R}\left[{ }^{\circ} \mathrm{C}\right] & \text { District heating return temperature } \\ T_{D C, S}\left[{ }^{\circ} \mathrm{C}\right] & \text { District cooling supply temperature } \\ T_{D C, R}\left[{ }^{\circ} \mathrm{C}\right] & \text { District cooling return temperature } \\ T_{H P C, S}\left[{ }^{\circ} \mathrm{C}\right] & \text { Heat pump condenser supply temperature } \\ T_{H P C, R}\left[{ }^{\circ} \mathrm{C}\right] & \text { Heat pump condenser return temperature } \\ T_{H P E, I}\left[{ }^{\circ} \mathrm{C}\right] & \text { Heat pump evaporator inlet temperature } \\ T_{H P E, O}\left[{ }^{\circ} \mathrm{C}\right] & \text { Heat pump evaporator outlet temperature } \\ T_{l m, H}\left[{ }^{\circ} \mathrm{C}\right] & \text { Logarithmic mean temperature of sink } \\ T_{l m, L}\left[{ }^{\circ} \mathrm{C}\right] & \text { Logarithmic mean temperature of source } \\ \Delta T_{D H}\left[{ }^{\circ} \mathrm{C}\right] & \text { Temperature difference between DH supply and return } \\ \Delta T_{H P C}\left[{ }^{\circ} \mathrm{C}\right] & \text { Temperature difference in HP condenser } \\ \Delta T_{D H, S}\left[{ }^{\circ} \mathrm{C}\right] & \text { Temperature drop in DH supply after HP junction } \\ \end{array}$

\section{References}

1. EUROSTAT. Renewable Energy for Heating and Cooling. Available online: https://ec.europa.eu/eurostat/ web/products-eurostat-news/-/DDN-20200211-1?inheritRedirect=true\&redirect=\%2Feurostat\%2F (accessed on 21 February 2020).

2. Pellegrini, M.; Bloemendal, M.; Hoekstra, N.; Spaak, G.; Andreu Gallego, A.; Rodriguez Comins, J.; Grotenhuis, T.; Picone, S.; Murrell, A.J.; Steeman, H.J. Low carbon heating and cooling by combining various technologies with Aquifer Thermal Energy Storage. Sci. Total Environ. 2019, 665, 1-10. [CrossRef]

3. Fleuchaus, P.; Godschalk, B.; Stober, I.; Blum, P. Worldwide application of aquifer thermal energy storage-A review. Renew. Sustain. Energy Rev. 2018, 94, 861-876. [CrossRef]

4. Hooimeijer, F.L.; Maring, L. The significance of the subsurface in urban renewal. J. Urban. 2018, 11, 303-328. [CrossRef] 
5. Schmidt, T.; Pauschinger, T.; Sørensen, P.A.; Snijders, A.; Djebbar, R.; Boulter, R.; Thornton, J. Design Aspects for Large-scale Pit and Aquifer Thermal Energy Storage for District Heating and Cooling. Energy Procedia 2018, 149, 585-594. [CrossRef]

6. Bonte, M.; Stuyfzand, P.J.; Hulsmann, A.; van Beelen, P. Underground thermal energy storage: Environmental risks and policy developments in the Netherlands and European Union. Ecol. Soc. 2011, 16, 15. [CrossRef]

7. Haehnlein, S.; Bayer, P.; Blum, P. International legal status of the use of shallow geothermal energy. Renew. Sustain. Energy Rev. 2010, 14, 2611-2625. [CrossRef]

8. Paiho, S.; Saastamoinen, H.; Hakkarainen, E.; Similä, L.; Pasonen, R.; Ikäheimo, J.; Rämä, M.; Tuovinen, M.; Horsmanheimo, S. Increasing flexibility of Finnish energy systems-A review of potential technologies and means. Sustain. Cities Soc. 2018, 43, 509-523. [CrossRef]

9. Popovski, E.; Aydemir, A.; Fleiter, T.; Bellstädt, D.; Büchele, R.; Steinbach, J. The role and costs of large-scale heat pumps in decarbonising existing district heating networks-A case study for the city of Herten in Germany. Energy 2019, 180, 918-933. [CrossRef]

10. Soltani, M.; Kashkooli, F.M.; Dehghani-Sanij, A.R.; Kazemi, A.R.; Bordbar, N.; Farshchi, M.J.; Elmi, M.; Gharali, K.B.; Dusseault, M. A comprehensive study of geothermal heating and cooling systems. Sustain. Cities Soc. 2019, 44, 793-818. [CrossRef]

11. Fleuchaus, P.; Schüppler, S.; Godschalk, B.; Bakema, G.; Blum, P. Performance analysis of Aquifer Thermal Energy Storage (ATES). Renew. Energy 2020, 146, 1536-1548. [CrossRef]

12. Harbaugh, A.W. MODFLOW-2005, The U. S. Geological Survey Modular Ground-Water Model-The Ground-Water Flow Process; US Department of the Interior, US Geological Survey: Reston, VA, USA, 2005.

13. SYKE. Finnish Environment Institute/Suomen Ympäristökeskus. Available online: https://www.syke.fi/en (accessed on 14 April 2020).

14. Joronen, L. Groundwater Protection Plan for Turku, Kaarina and Rusko Orig. Title “Turun, Kaarinan ja Ruskon Pohjavesialueiden Suojelusuunnitelma". Available online: https:/www.turku.fi/sites/default/files/ atoms/files/2010-turun_kaarinan_ja_ruskon_pohjavesialueiden_suojelusuunnitelma.pdf (accessed on 20 February 2020).

15. Bayer, P.; Attard, G.; Blum, P.; Menberg, K. The geothermal potential of cities. Renew. Sustain. Energy Rev. 2019, 106, 17-30. [CrossRef]

16. NLSF. National Land Survey of Finland. Available online: https://iedostopalvelu.maanmittauslaitos.fi/tp/ kartta?lang=en (accessed on 14 April 2020).

17. QGIS. QGIS-The Leading Open Source Desktop GIS. Available online: https://www.qgis.org/en/site/about/ index.html (accessed on 12 March 2020).

18. Reinholdt, L.; Kristófersson, J.; Zühlsdorf, B.; Elmegaard, B.; Jensen, J.; Ommen, T.; Jørgensen, P.H. Heat pump COP, part 1: Generalized method for screening of system integration potentials. In Proceedings of the 13th IIR Gustav Lorentzen Conference on Natural Refrigerants (GL2018), Valencia, Spain, 18-20 June 2018.

19. GRUNDFOS. Grundfos SP Submersible Pumps. Available online: https://www.grundfos.com/products/findproduct/sp.html (accessed on 17 February 2020).

20. EUROHEAT. Guidelines for District Heating Substations, Approved by the Euroheat \& Power Board. Available online: https:/www.euroheat.org/wp-content/uploads/2008/04/Euroheat-Power-GuidelinesDistrict-Heating-Substations-2008.pdf (accessed on 12 February 2020).

21. GRUNDFOS. Grundfos NB/NBG Centrifugal Pumps. Available online: https://www.grundfos.com/products/ find-product/nb-nbg-nbe-nbge.html (accessed on 17 February 2020).

22. USGS. ModelMuse: A Graphical User Interface for Groundwater Models. Available online: https://www.usgs. gov/software/modelmuse-a-graphical-user-interface-groundwater-models (accessed on 16 March 2020).

23. Todorov, O.; Alanne, K.; Virtanen, M.; Kosonen, R. A method and analysis of aquifer thermal energy storage (ATES) system for district heating and cooling: A case study in Finland. Sustain. Cities Soc. 2020, 53, 101977. [CrossRef]

24. RMSE. Root-Mean-Square Deviation. Available online: https://en.wikipedia.org/wiki/Root-mean-square deviation (accessed on 16 April 2020).

25. MAE. Mean Absolute Error. Available online: https://en.wikipedia.org/wiki/Mean_absolute_error (accessed on 16 April 2020).

26. Luoma, S. Groundwater Flow Models of the Shallow Aquifer in Hanko. Available online: http://tupa.gtk.fi/ raportti/arkisto/95_2018.pdf (accessed on 10 February 2020). 
27. Nielsen, S.; Möller, B. GIS based analysis of future district heating potential in Denmark. Energy 2013, 57, 458-468. [CrossRef]

28. Danish Energy Agency. Technology Data for Generation of Electricity and District Heating. Available online: https://ens.dk/en/our-services/projections-and-models/technology-data/technology-data-generationelectricity-and (accessed on 17 February 2020).

29. Drenkelfort, G.; Kieseler, S.; Pasemann, A.; Behrendt, F. Aquifer thermal energy storages as a cooling option for German data centers. Energy Effic. 2015, 8, 385-402. [CrossRef]

30. NORDPOOL. Nordpool Finnish Day-Ahead Monthly Prices 2006-2020. Available online: https://www. nordpoolgroup.com/Market-data1/Dayahead/Area-Prices/FI/Monthly/?dd=FI\&view=table (accessed on 16 March 2020).

31. Schüppler, S.; Fleuchaus, P.; Blum, P. Techno-economic and environmental analysis of an Aquifer Thermal Energy Storage (ATES) in Germany. Geotherm. Energy 2019, 7, 11. [CrossRef]

32. Vanhoudt, D.; Desmedt, J.; Van Bael, J.; Robeyn, N.; Hoes, H. An aquifer thermal storage system in a Belgian hospital: Long-term experimental evaluation of energy and cost savings. Energy Build. 2011, 43, 3657-3665. [CrossRef]

33. Finnish Energy District Heating in Finland. 2017. Available online: https://energia.fi/files/2948/District_ heating_in_Finland_2017.pdf (accessed on 16 March 2020).

34. Guzzini, A.; Pellegrini, M.; Pelliconi, E.; Saccani, C. Low temperature district heating: An expert opinion survey. Energies 2020, 13, 810. [CrossRef]

(C) 2020 by the authors. Licensee MDPI, Basel, Switzerland. This article is an open access article distributed under the terms and conditions of the Creative Commons Attribution (CC BY) license (http://creativecommons.org/licenses/by/4.0/). 